\title{
Potencjał badań edukacyjnych bazy danych Internetowej Rejestracji Kandydatów - metoda analityczna desk research
}

KEYWORDS

education, research, Online Candidate Registration, IRK, archeology, desk research

\begin{abstract}
Filip Nalaskowski, Dagna Dejna, Potencjałbadań edukacyjnych bazy danych Internetowej Rejestracji Kandydatów metoda analityczna desk research [Online Candidate Registration database educational study potential - desk research analytical method]. Kultura - Społeczeństwo Edukacja nr 2(18) 2020, Poznań 2020, pp. 423-437, Adam Mickiewicz University Press. ISSN 2300-0422. DOI 10.14746/kse.2020.18.16.1.

The text presents and describes the desk research analytical method. As an example of the practical application of the described method and a little-known data source, a short analysis of the database of Online Registration of Candidates is presented. The components of the base are presented step by step, along with its information potential. A separate part is the presentation of the possible potential of IRK for educational research - in this case 11 years of candidates for archaeological studies at the Nicolaus Copernicus University. Analysis of the candidates' origin, study potential, determination to take a specific major, etc.
\end{abstract}

\section{Wstęp}

Metoda desk research polega na sięganiu po dane zastane w celu włączania ich do procesu badawczego. Źródła danych zastanych mają wiele zalet, również dla badaczy społecznych. Przede wszystkim korzystanie z nich wiąże się z niewielkimi kosztami finansowymi oraz nakładami organizacyjnymi. Metoda generuje niewielkie koszty,

* ORCID: 0000-0001-6973-9960.

** ORCID: 0000-0003-0722-1992. 
nie obciąża środowiska, nie zwiększa zagrożenia epidemiologicznego. W obliczu aktualnych wyzwań społecznych i niebezpieczeństw argumenty te zasługują na uwagę.

Wtórna analiza danych może stanowić metodę uzupełniającą w procesie gromadzenia danych i rozwiązywania problemów badawczych, może też być głównym i jedynym źródłem informacji - jak ma to miejsce w projekcie opisywanym w naszym tekście. Wielką zaletą metody desk research jest to, że możliwe jest prowadzenie analiz na wielkich próbach badawczych. Wadą w odniesieniu do naszego przedsięwzięcia badawczego jest zdecydowanie to, że jako badacze nie mieliśmy wpływu na kształt narzędzia do gromadzenia danych, sposób ich gromadzenia oraz przechowywania, a także dobór zmiennych.

Źródłami danych wykorzystanymi na potrzeby prezentowanego tekstu są baza Internetowej Rejestracji Kandydatów (dalej IRK) oraz informacje pochodzące z Uczelnianej Komisji Rekrutacyjnej (dalej UKR). Na wykorzystanie i publikację tych danych otrzymaliśmy zgodę prorektora Uniwersytetu Mikołaja Kopernika w Toruniu ds. studenckich i polityki kadrowej.

Wydaje się, że wciąż niewielu badaczy interesujących się wątkami kształcenia na studiach wyższych - a nawet szczerzej: edukacją i problemami społecznymi ma świadomość istnienia baz IRK oraz zna ich potencjał informacyjny. IRK to baza danych, w której znajdują się informacje o milionach osób mogących zostać przedmiotem zainteresowania badaczy społecznych.

Każdy $\mathrm{z}$ kandydatów na studia musi podać dane osobowe, a także - co ciekawsze - dane o pochodzeniu, ścieżce edukacyjnej, wynikach w nauce (np. oceny z egzaminu dojrzałości czy studiów I stopnia). Każda z rejestrujących się osób deklaruje także swoje wybory dotyczące planowanych kierunków kształcenia.

Co ważne, opisywane źródło nie cieszyło się do tej pory prawie żadnym zainteresowaniem badaczy ${ }^{1}$, dlatego warto przyjrzeć mu się bliżej. W tekście tym zawarto informacje o tym, jakie dane baza IRK zawiera, jak zdobyć do niej dostęp i jaki drzemie w niej potencjał badawczy.

\section{Desk research i egzemplifikacje potencjalnych źródel danych}

W dobie powszechnego dostępu do Internetu, badań prowadzonych w ramach rozbudowanego programu statystki publicznej (np. Główny Urząd Statystyczny), a nade wszystko tendencji do upowszechniania i dzielenia się wynikami badań

${ }^{1}$ Dział rekrutacji Uniwersytetu Mikołaja Kopernika w Toruniu poinformował nas, że od początku funkcjonowania systemu na uczelni, tj. od 2007 roku, tylko autorzy tego tekstu potraktowali bazę IRK jako źródło informacji do badań. 
projekty desk research zależą w głównej mierze od umiejętności i talentu badacza. Do badań z dziedziny nauk społecznych z powodzeniem wykorzystywane są opisy, streszczenia, raporty, bazy danych (np. Diagnoza Społeczna, Polski Generalny Sondaż Społeczny, Polski Generalny Sondaż Wyborczy, European Social Survey, World Value Survey, International Social Survey Programme).

Takie projekty zakładają udostępnianie nie tylko raportów, ale także baz danych z możliwością wykonania samodzielnych analiz. Jednym z wyzwań może być zapoznanie się z bazą, sposobem kodowania zmiennych i poznanie wszystkich ograniczeń analitycznych (np. zbyt mała próba, próba niezrealizowana w danym obszarze, brak danych za jeden rok). Ponadto powstaje bardzo dużo projektów na zlecenie instytucji publicznych, które są publikowane i powszechnie dostępne (np. Urzędu Ochrony Konkurencji i Konsumentów, Polskiej Agencji Rozwoju Przedsiębiorczości) (Bednarowska, 2015).

\section{SUEK}

Źródła wtórne powstające przy udziale instytucji realizujących badania edukacyjne pełne są danych czekających na analizę. Dobrym przykładem takiej bazy danych czekającej na interpretację (czy raczej na kolejne interpretacje) jest ta powstała na potrzeby badań prowadzonych przez Instytut Badań Edukacyjnych nad szkolnymi uwarunkowaniami efektywności kształcenia. Prace specjalnie powołanego zespołu badawczego koncentrowały się na identyfikacji kluczowych czynników warunkujących efektywność kształcenia w szkołach podstawowych. Badanie SUEK było badaniem podłużnym o charakterze ilościowym, prowadzonym na reprezentatywnej, ogólnopolskiej próbie szkół podstawowych. Główne pytania badawcze dotyczyły związku między cechami środowiska szkolnego a efektywnością kształcenia w szkołach podstawowych. Na stronie internetowej Instytutu Badań Edukacyjnych zamieszczono gigantyczną bazę danych, której potencjał badawczy i analityczny jest nie do przecenienia. To efekt pracy zespołu badawczego, wysiłkiem którego dotarto do 177 szkół podstawowych i zbadano 5500 uczniów. Zamieszczone tam bazy danych ułożone są chronologicznie, uwzględniono etap badania oraz podział na poszczególnych respondentów, którymi byli: uczniowie, rodzice uczniów, ich nauczyciele oraz dyrektorzy (szkoły). Wykorzystanie udostępnionych baz odbywa się pod warunkiem uprzedniego kontaktu $\mathrm{z}$ autorami oraz pod warunkiem zamieszczenia w przypisach późniejszych publikacji stosownej klauzuli informującej o źródle danych².

\footnotetext{
${ }^{2}$ Zob. http://eduentuzjasci.pl/bazy-danych.html [dostęp: 02.03.2020].
} 


\section{Inne}

Wartościowym źródłem informacji o potencjale edukacyjnym i społecznym jest publikowany przez GUS raport „Nauka i technika”. W raporcie tym przedstawiono dane statystyczne zestawione w perspektywie 10-15 lat dla Polski i wybranych państw UE dotyczące nakładów na działalność badawczą i rozwojową, personelu w działalności badawczej i rozwojowej, a także zasobów ludzkich dla nauki i techniki.

Źródłem informacji na temat rozwoju poszczególnych województw są również regionalne sieci transferu technologii (RSTT), regionalnego systemu wspierania innowacji (RSWI), jak również bazy dotyczące technologii i rozwiązań innowacyjnych ośrodków akademickich i instytutów badawczych.

W przypadku informacji na temat technologii istnieje wiele funkcjonujących baz, np. baza wiedzy o nowych technologiach prowadzona przez Ministerstwo Gospodarki i baza technologii, przedsiębiorstw i produktów innowacyjnych zarządzana przez Ośrodek Przetwarzania Informacji oraz RSTT.

W przypadku baz dotyczących struktury i wielkości nakładów ponoszonych na rozwój sfery nauki i badań wspomnieć warto o bazach Ministerstwa Nauki i Szkolnictwa Wyższego (baza Nauka Polska, system POL-on, bazy zgłoszonych do NCN i NCBiR projektów, jak również bazy regionalne, np. bazy portalu województwa łódzkiego Nauka i Biznes ${ }^{3}$.

Wszystkie wspomniane wyżej bazy danych są potencjalnym źródłem informacji i mogą zostać wykorzystane do realizacji dowolnego pomysłu badawczego.

\section{POL-On}

Zanim przejdziemy do opisu bazy danych Internetowej Rejestracji Kandydatów, warto jeszcze przywołać bazę, a właściwie system informatyczny o nazwie POL-on oraz wskazać możliwy zakres i cel wykorzystania gromadzonych tam danych. Tematyka/zakres danych:

- rejestr uczelni niepublicznych i związków uczelni niepublicznych;

- zestawienie prowadzonych studiów na kierunkach;

- rejestr instytucji szkolnictwa wyższego;

- rejestr jednostek naukowych;

${ }^{3}$ Zob. https://www.gig.eu/sites/default/files/attachments/przetargi/2013_03_27_struktura_bazy_ danych_zweryfikowana_fin.pdf [dostęp: 04.03.2020]. 
- instytucje kościelne;

- uprawnienia jednostek do nadawania stopni naukowych;

- zestawienie osób ze stopniami i tytułami naukowymi.

Potencjalny zakres i cel wykorzystania powyższych danych to między innymi zebranie pełnej informacji na temat instytucji szkolnictwa wyższego. Dzięki danym możliwe jest określenie, jakiego typu instytucje, jakie kierunki studiów oraz jakie obszary nauki rozwijane są w kraju, również w ujęciu regionalnym. Umożliwia to diagnozę stanu kapitału społecznego i ludzkiego oraz zasobów infrastrukturalnych, co może zostać uwzględnione podczas określania endogenicznego potencjału poszczególnych regionów i kraju .

\section{Informacje podstawowe i zasady działania Internetowej Rejestracji Kandydatów}

Rekrutacja na Uniwersytet Mikołaja Kopernika to całościowy proces związany z przyjęciem kandydata na studia, natomiast sama rejestracja stanowi zaledwie pierwszy etap rekrutacji i jest dokonywana drogą internetową właśnie w IRK. Wypełnienie formularzy w aplikacji to pierwszy etap postępowania. Na kolejnym należy zapisać się na dany kierunek, wnieść opłatę rekrutacyjną, a następnie, po uzyskaniu informacji o przyjęciu na studia, dostarczyć komplet dokumentów do UKR 5 .

Internetowa Rejestracja Kandydatów to system służący usprawnieniu procesu rekrutacji na studia wyższe na uczelniach publicznych w Polsce. Dotyczy on naboru na studia jednolite, pierwszego i drugiego stopnia oraz do szkół doktorskich, zarówno na studia stacjonarne, jak i niestacjonarne, wieczorowe, w zasadzie na wszystkie tryby z wyłączeniem studiów podyplomowych czy ewentualnych otwartych kursów.

System istnieje od 2005 roku i obecnie obejmuje swoim zasięgiem 39 polskich uczelni wyższych. Pomysłodawcą systemu był Uniwersytet Warszawski, obecnie jego głównym administratorem i właścicielem jest MUCI (Międzyuczelniane Centrum Informatyzacji ${ }^{6}$. Aby poprawnie oszacować wielkość bazy, należy wziąć pod uwagę fakt, że na Uniwersytecie Mikołaja Kopernika system działa od 2007 roku i corocznie rejestruje się w nim (podaje dane) około 20000 osób, co w skali

\footnotetext{
${ }^{4}$ Zob. https://www.gig.eu/sites/default/files/attachments/przetargi/2013_03_27_struktura_ bazy_danych_zweryfikowana_fin.pdf [dostęp: 04.03.2020].

${ }^{5}$ Por. https://www.umk.pl/kandydaci/niezbednik/faq/ [dostęp: 10.02.2019].

${ }^{6}$ Zob. muci.edu.pl [dostęp: 10.01.2020].
} 
całego kraju daje miliony użytkowników na przestrzeni wielu lat funkcjonowania systemu.

Każdy z kandydatów zobowiązany jest do założenia konta w systemie ${ }^{7}$. Użytkownicy logują się w systemie za pomocą PESEL-u, który stanowi też indywidualny, niepowtarzalny login. Hasło wybierają sami. Następnie podają informacje o sobie, posługując się formularzami widocznymi na ekranie. Są to:

- informacje podstawowe: imię, data urodzenia, płeć, obywatelstwo,

- dane kontaktowe (adres, e-mail, telefon),

- dane dotyczące wykształcenia (średniego, wyższego, udziału w olimpiadach czy zdobytych certyfikatów),

- inne dane, jak informacje o dowodzie tożsamości czy stosunku do służby wojskowej,

- zdjęcie - wykorzystane później do stworzenia legitymacji studenckiej.

Po tych czynnościach kandydat może wybrać kierunki studiów, na które chce się zapisać. W zależności od trybu i stopnia procedura ta może wyglądać nieco inaczej. Na przykład na stacjonarne studia I stopnia może obowiązywać system priorytetów. Polega on na tym, że kandydat wybiera dowolną liczbę kierunków, na których mu zależy, szereguje je według priorytetu (stopnia zainteresowania/pożądania). Kandydaci zobowiązani są też do uiszczenia opłaty za każdy wybrany przez siebie kierunek. W wynik procesu kwalifikacyjnego kandydat jest przyjmowany na kierunek o najwyższym priorytecie, na który pozwala mu liczba osiągniętych punktów (rysunek 1). Punkty rekrutacyjne obliczane są na podstawie ocen z egzaminu dojrzałości, egzaminów wstępnych czy wyniku studiów I stopnia (w przypadku aplikowania na II stopień).

Do realizacji powyższego celu konieczne jest umieszczenie w systemie danych umożliwiających policzenie punktów. W przypadku studiów I stopnia kwestia ta jest znacząco uproszczona przez funkcjonowanie systemu KReM (Krajowy Rejestr Matur), z którego to wszystkie oceny są automatycznie pobierane (rysunek 2). Oznacza to, że dane te nie wymagają dalszej weryfikacji. Pozostali kandydaci (mający „stare” matury, matury zagraniczne czy wyniki ze studiów I stopnia) muszą wpisać oceny i wyniki samodzielnie - dane te są weryfikowane przy składaniu dokumentów przez członków Uczelnianej Komisji Rekrutacyjnej.

${ }^{7}$ Opis i ilustracje dotyczą ściśle systemu IRK stosowanego do 2020 roku - wersji starszej interfejsu. Zmianie uległ głównie wygląd - zestaw zbieranych danych, natomiast zasady funkcjonowania nie uległy modyfikacjom. 


\section{Zapisy na studia}

Lingwistyka stosowana (s1) - język włoski z językiem arabskim lub czeskim lub hiszpańskim

Dodano: 2019-05-14 10:55 Priorytet: $1+z$ nień ścieżka: MATURA
Wyniki rekrutacji
Wynik: 49.8 pkt.
Decyzja kwalifikacyjna: kandydat niezakwalifikowany na studia
Decyzja dotyczaca przyjęcia na studia: kandydat nie zostal przyjęty na studia
Pozycja na liście: 109
Uwagi: Kandydat niezakwalifikowany na studia w tej turze rekrutacji.

\section{Filologia włoska (s1)}

Wodano: $2019-05-14$ 10:5 Prorytet: $2+$ mień ścieżka: MATURA
Wynik: 47 pkt.
Decyzja kwalifikacyjna: kandydat zakwalifi kowany
Decyzja dotyczaca przyjęcia na studia: kandydat został przyjęty na studia
Pozycja na liście: 68
Uwagi: Dokumenty zostały już złożone.

\section{Dziennikarstwo i komunilikacja społeczna (s1)}

Dodano: 2019-05-14 10:59 Priorytet: $3+z$ nień ścieżka: MATURA
Wyniki rekrutacji
Wynik: 41.5 pkt.
Decyzja kwalifikacyjna: kandydat niezakwalifikowany na studia
Decyzja dotyczaca przyjęcia na studia: kandydat nie zostal przyjęty na studia
Pozycja na liście: 129
Uwagi: Niezakwalifikowany z powodu zakwalifikowania na kierunek o wyższym priorytecie.

\section{Rysunek 1. Przykładowa zakładka „Priorytety”}

Źródło: opracowanie własne.

Wyniki egzaminów

\begin{tabular}{|c|c|c|c|}
\hline Egzamin & Wynik & & \\
\hline Specjalizacja dziennikarstwo i nowe media & wyniki nie sa dostępne & są dostępne & \\
\hline Specjalność język włoski z językiem czeskim & wyniki nie są dostępne & są dostępne & \\
\hline Specjalność język włoski z językiem hiszpańskim & \multicolumn{2}{|c|}{ wyniki nie są dostępne } & \\
\hline \multicolumn{2}{|l|}{ Matura } & $\begin{array}{l}\text { Wynik wpisany przez } \\
\text { kandydata }\end{array}$ & Wynik z KREMu \\
\hline \multicolumn{2}{|l|}{ Matura, język angielski } & $\begin{array}{l}\text { podst.: } 86 \% \\
\text { rozsz.: } 46 \%\end{array}$ & $\begin{array}{r}\text { podst.: } 86 \% \\
\text { rozsz.: } 46 \% \\
\text { rok: } 2019\end{array}$ \\
\hline \multicolumn{2}{|l|}{ Matura, język polski } & $\begin{array}{l}\text { podst.: } 61 \% \\
\text { rozsz.: } 48 \%\end{array}$ & $\begin{array}{r}\text { podst.: } 61 \% \\
\text { rozsz.: } 48 \% \\
\text { rok: } 2019\end{array}$ \\
\hline \multicolumn{2}{|l|}{ Matura, matematyka } & podst. : $70 \%$ & $\begin{array}{r}\text { podst.: } 70 \% \\
\text { rok: } 2019\end{array}$ \\
\hline \multicolumn{2}{|c|}{$\begin{array}{l}\text { Język polski - egzamin maturalny (na podstawie zaświadczenia z } \\
\text { OKE) }\end{array}$} & BRAK & rozsz.: $48 \%$ \\
\hline \multicolumn{2}{|c|}{$\begin{array}{l}\text { Matematyka - egzamin maturalny (na podstawie zaświadczenia z } \\
\text { OKE) }\end{array}$} & BRAK & podst.: $70 \%$ \\
\hline
\end{tabular}

Rysunek 2. Przykładowa zakładka „Wyniki egzaminów”

Źródło: opracowanie własne. 
Laureaci olimpiad przedmiotowych i sportowcy często mogą liczyć na ulgi $\mathrm{w}$ procesie rekrutacyjnym (np. wolny wstęp na wybrane kierunki czy zwolnienie z opłat rekrutacyjnych). Po zadeklarowaniu w systemie posiadania takiego prawa zobowiązani są do dostarczenia dokumentów potwierdzających to, które następnie są weryfikowane przez komisję.

Kandydaci zobowiązani są też do uiszczenia opłaty za każdy wybrany przez siebie kierunek. W systemie mają podgląd statusu swoich płatności oraz widzą wyniki rekrutacji. System jest też platformą kontaktu między kandydatami a osobami obsługującymi rekrutacje na uczelniach.

\section{Charakterystyka bazy danych - szczegółowe informacje o systemie Internetowej Rejestracji Kandydatów}

W procesie rekrutacji zbierane są dane konieczne do przyjęcia kandydatów. Większość danych podają sami zainteresowani, jak na przykład dane osobowe czy wyniki z dyplomów ukończenia studiów pierwszego stopnia, część wypełniana jest automatycznie - „zaciągana” do systemu z zewnątrz (w przypadku ocen maturalnych).

\section{Dane podawane przez kandydatów}

Większość danych podaje się w podstronie „Moje dane osobowe” (rysunek 3). Informacje podzielone są na następujące zakładki i zapytania:

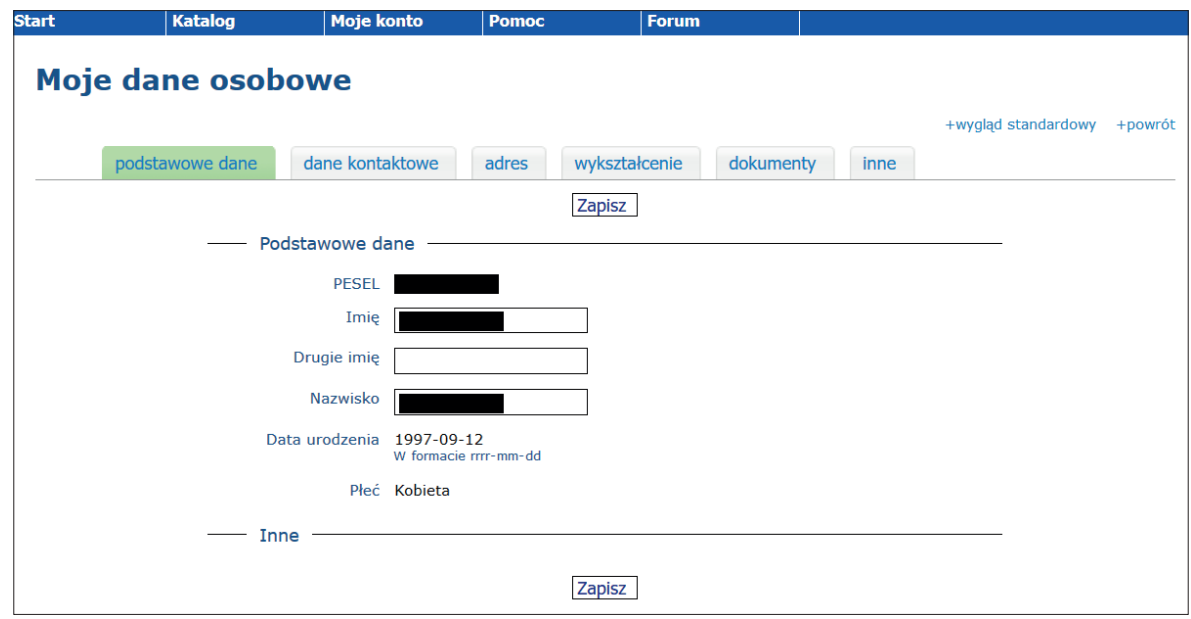

Rysunek 3. Podstrona „Moje dane osobowe”

Źródło: opracowanie własne. 
Dane podstawowe:

- PESEL (domyślnie uzupełniony przez system),

- imię,

- drugie imię,

- nazwisko,

- data urodzenia (domyślnie uzupełniona na podstawie PESEL-u),

- płeć (domyślnie uzupełniona na podstawie PESEL-u).

Dane kontaktowe:

- adres e-mail,

- telefon,

- telefon komórkowy.

Dane adresowe:

- adres zameldowania,

- rodzaj adresu (do wyboru: miasto, mała miejscowość lub wieś; adres zagraniczny),

- kod pocztowy,

- województwo (do wyboru z listy),

- miejscowość,

- ulica,

- numer domu,

- numer mieszkania.

Dane dotyczące wykształcenia:

- nazwa ukończonej szkoły średniej (wybór z listy; podanie szkoły spoza listy),

- miejscowość (domyślnie uzupełniona na podstawie wyboru z listy nazw),

- rok uzyskania matury (najwcześniej uzyskanej),

- numer indeksu (jeśli kandydat był już studentem danej uczelni),

- dokument uprawniający do podjęcia studiów (lista dokumentów do wyboru: nowa matura (zdawana od 2005 roku) lub IB lub EB; stara matura (sprzed 2005 roku); matura zagraniczna; dyplom licencjata lub równoważny; dyplom magistra lub równoważny; dyplom zagraniczny uprawniający do podjęcia studiów II stopnia; tytuł laureata lub finalisty olimpiady przedmiotowej),

- numer wybranego dokumentu,

- data wystawienia,

- instytucja wydająca dokument (nazwa i miejscowość - w przypadku matur i dyplomów wybierane z listy rozwijanej). 
Dokumenty/załączniki (alternatywnie w tej części kandydaci mogą przesłać elektroniczną wersję istotnych dokumentów).

Inne, dodatkowe informacje osobowe:

- rodzaj dowodu tożsamości,

- numer dowodu tożsamości,

- kraj wydania dokumentu,

- miejsce urodzenia,

- kraj urodzenia,

- obywatelstwo,

- nazwisko rodowe (u mężatki),

- imię ojca,

- imię matki.

Dodatkowe informacje rekrutacyjne:

- czy chcesz zamieszkać w akademiku (odpowiedź wybierana z listy).

Informacje dotyczące służby wojskowej:

- stosunek do służby wojskowej (odpowiedź wybierana z listy),

- kategoria wojskowa (odpowiedź wybierana z listy),

- WKU (odpowiedź wybierana z listy).

Zestaw danych opisanych wyżej jest następnie uzupełniany o:

- wyniki egzaminów maturalnych, egzaminów na studia lub wyniki ze studiów pierwszego stopnia,

- wybrane przez kandydata kierunki studiów, na które chce aplikować.

\section{Dostęp do bazy i aspekty prawne}

Dostęp do opisywanej bazy danych mają, niejako z definicji, pracownicy uczelni zaangażowani w rekrutację, tj.: kadra zarządzająca uczelnią, działy administracji uczelnianej odpowiedzialne za rekrutację, komisje rekrutacyjne, ewentualnie egzaminacyjne oraz administratorzy aplikacji. Na UMK dostęp co roku otrzymuje około 100 osób. Pojawia się pytanie: co z osobami spoza uczelni chcącymi pracować w opisywanej bazie, wykorzystując ją na przykład do celów badawczych? Dysponentem danych, w przypadku UMK i innych uczelni państwowych, jest rektor. 
Trzeba też zauważyć, że z formalnego punktu widzenia nie można pracować badawczo na danych osobowych, bowiem nie wyrazili na to zgody zapisujący się w systemie. Jak twierdzą specjaliści, przepisy RODO uniemożliwiałyby prowadzenie badań w IRK odwołujących się stricte do danych osobowych ${ }^{8}$. Można jednak prowadzić badania o charakterze zbiorczym („statystycznym”). Jest to dopuszczone - nie znajdują tu ścisłego zastosowania przepisy o RODO.

\section{Autorski przykład zastosowania prakłycznego bazy Internetowej Rejestracji Kandydatów}

W 2017 roku prowadziliśmy w duecie badania właśnie na podstawie bazy Internetowej Rejestracji Kandydatów UMK. Celem badań była próba zbudowania charakterystyki kandydata na studia archeologiczne na UMK. Zakres badań obejmował lata 2007-2017, a zatem 11 roczników rekrutacyjnych (nabór na stacjonarne studia pierwszego stopnia).

Dla podejmowanych analiz archeologia jest o tyle ciekawa, że stanowi przykład kierunku, którego nabory dramatycznie stopniały w ciągu dekady - od 120 do 20 kandydatów na pierwszy rok pierwszego stopnia. Co więcej, w opiniach samych prowadzących „jakość” kandydatów wyraźnie się obniżyła. Badania pozwoliły zweryfikować przytoczone wyżej tezy oraz pomóc w poszukiwaniu rozwiązań dla poprawy sytuacji. Ustalenia powyższe stały się także przedmiotem tekstów naukowych znajdujących się obecnie w procesie recenzyjnym.

W wyniku opracowanych danych udało się uzyskać wiele informacji i poczynić pewne ustalenia. Oto przykładowe dane:

- liczebność roczników naboru,

- proporcja płci,

- typ ukończonych szkół średnich,

- średnie wyniki z matur, rodzaj matur, a także wyniki z poszczególnych (ważnych dla archeologii) przedmiotów, jak np. historii, geografii czy biologii,

- miejscowość, z której pochodzili badani/kandydaci (gdzie kończyli szkoły średnie), odległość szkół średnich od Torunia,

- typ miejscowości (miasto, wieś),

- wiek kandydatów,

- inne kierunki studiów wybierane przez kandydatów.

\footnotetext{
${ }^{8}$ Informacja udzielona nam bezpośrednio od inspektora ochrony danych na UMK - Jakuba Rutkowskiego.
} 
Wyżej wymienione informacje należą raczej do tych prostszych, stricte statystycznych ustaleń, ale jak wspomniano wcześniej, baza daje możliwość konstruowania także bardziej złożonych kategorii, a co za tym idzie - poszukiwania odpowiedzi na trudniejsze pytania:

- Jakie kierunki stanowią konkurencję dla archeologii, jak na ich tle wypada archeologia?

- Jakie są prognozy dla liczebności naborów i „jakości” kandydatów?

Ciekawymi kategoriami, wręcz osiowymi, które spróbowaliśmy stworzyć, były: siła kandydata i siła motywacji. Siła kandydata to wartość opisująca, na podstawie dostępnych nam danych, potencjał intelektualny i kulturowy kandydata. Innymi słowy, czy jest to materiał na silnego naukowo studenta. Druga $\mathrm{z}$ kategorii - siła motywacji - odpowiada na pytanie, na ile kandydat był zdeterminowany do podjęcia danego kierunku studiów. Czy nie było tak, że znalazł się tu przypadkiem albo ze względu na brak lepszej alternatywy?

Pierwotne badanie dotyczyło archeologii, ale wypracowany mechanizm i sposób analizy można wykorzystać w budowaniu charakterystyk wszystkich pozostałych kierunków kształcenia akademickiego.

Pierwsza $\mathrm{z}$ tych kategorii była $\mathrm{w}$ zasadzie tym, co wykładowcy nazywali „jakością" studentów. Obliczana była ze składowych, takich jak: typ i „jakość" ukończonej szkoły średniej, liczba egzaminów maturalnych, średni wynik ze wszystkich egzaminów maturalnych, punkty rekrutacyjne uzyskane w IRK, fakt bycia olimpijczykiem. Druga z kategorii budowana była na podstawie: odległości zamieszkania od Torunia, sposobu ustalenia priorytetowych kierunków w rekrutacji, rocznika.

Pozyskane informacje dały podstawy do sformułowania ostrożnych wniosków. Poniżej przytaczamy niektóre z ustaleń, które w całości zbudowaliśmy, wykorzystując dane z IRK.

1. Liczebność naborów może być ujęta w trzech stadiach: prosperity, gwałtownego spadku, niskiej stagnacji/odbicia. Odpowiednio odpowiadają one naborom 2007-2009 (prosperity) średnio 103 przyjmowanych, 2010-2014 (gwałtowny spadek) z 90 do 19, 2015-2017 (stagnacja i delikatne odbicie) to 18-22 kandydatów.

2. W pierwszych pięciu latach dominowały, wśród kandydatów, osoby wyraźnie przyjezdne (100 i więcej kilometrów), w drugim okresie mamy tendencję odwrotną - dominują osoby z regionu (do $100 \mathrm{~km}$ ).

3. Można też powiedzieć, że w skali 11 analizowanych lat kierunek archeologia jest lekko sfeminizowany, bo 56\% (392) kandydatów przyjętych w poczet studentów to kobiety. 
4. Aż $24 \%$ badanych (168 osób) było absolwentami jednej z najlepszych dla swojego województwa szkół średnich (pierwsze 15 szkół wg rankingu „Perspektyw”).

5. Jedynie nieco ponad połowa kandydatów zdawała na maturze poziom podstawowy z historii - wydawać by się mogło: przedmiot kanoniczny dla archeologii. Ale już aż 10\% tak „egzotyczną” historię sztuki. Wskazywano czasami jako pokrewne, pomocnicze $\mathrm{w}$ archeologii biologię i geografię, odpowiednio $9 \%$ i $30 \%$.

6. Analiza ukazanych danych pokazuje też, że w ogólnym oglądzie studenci archeologii notują wysokie wyniki na maturze. Najlepiej wypadają z historii, geografii, WOS-u i języka angielskiego. Najwięcej kłopotów przysparzają im przedmioty ścisłe i przyrodnicze (matematyka, chemia, biologia) i język niemiecki - gdzie wypadają poniżej średniej.

7. Bardzo ciekawe ustalenia przynosi analiza priorytetów przy wyborze kierunków na studia. W zasadzie wśród młodych archeologów ich dyscyplina zawsze wygrywała w konkurencji priorytetów. Grupa kierunków wyłamujących się z tego trendu jest stosunkowo nieliczna: prawo, konserwacja, bezpieczeństwo wewnętrzne - te zazwyczaj były jako alternatywy wyżej cenione od archeologii. Najczęściej konkurencją dla archeologii była historia - prawie $15 \%$ osób także na nią startowało, ale uwaga: dla nikogo $\mathrm{z}$ badanych nie miała ona wyższego priorytetu (sic!) - nikt z młodych archeologów nie wolałby studiować historii.

W nawiązaniu do kategorii sił udało się między innymi ustalić, że okresowi „prosperity” w latach 2007-2010 (liczne nabory) towarzyszył jednak subtelny spadek siły motywacji do studiowania archeologii i siły intelektualnej/kulturowej kandydatów. Trend spadkowy w naborach koreluje z dynamiczniejszym spadkiem opisywanych sił u kandydatów. Po kryzysowym roku 2014 następuje bardzo subtelny wzrost liczby kandydatów (o około 10-15\%) oraz wyraźny wzrost motywacji i siły. Innymi słowy, w ostatnich trzech latach kandydatów jest mniej, ale mają oni wysoką motywację i dużą wartość siły intelektualnej oraz kulturowej na tle poprzednich roczników.

\section{Ważenie zmiennych - próbka własnego warsztatu metodologicznego}

Poszukując wartości wagowych dla opisywanych zmiennych, musieliśmy się często odwoływać do rozstrzygnięć arbitralnych, opartych na naszej wiedzy pedagogicznej i doświadczeniu przy prowadzeniu podobnych badań. 
Pierwszą z takich zmiennych była jakość (siła) ukończonej szkoły średniej. Wychodziliśmy z założenia, że ma ona znaczenie, może być zmienną dla określania sity kandydata. Szkoła średnia jest swoistą szklarnia, w której dorasta kandydat. To, jaką ofertę stwarza uczniom, na ile ma potencjał do stymulowania ich rozwoju, jaki panuje tam klimat naukowy, jakie są jej osiągnięcia, będzie się przekładać na rozwój ucznia, przyszłego kandydata na studia. Analogicznie szkoły słabsze, stwarzające gorsze warunki do wzrostu będą „,wypuszczać” słabszych kandydatów. Wszystko to będzie ujawniać się nie tylko w łatwo mierzalnych wskaźnikach takich jak wyniki matur.

Zmienną, o której mowa, postanowiliśmy szeregować trójstopniowo, na podstawie rankingu szkół wyższych czasopisma „Perspektywy”. Absolwenci pierwszych pięciu szkół w danym województwie otrzymywali +25 punktów, analogicznie absolwenci ostatnich pięciu szkół w rankingu -25 punktów, pozostali 0 . Wartości punktowe zostały ustalone na zasadzie oszacowania i proporcji. Nie chcieliśmy premiować (czy też karać) tym wynikiem badanych. Zadecydowaliśmy (arbitralnie), że siła tej zmiennej może odpowiadać około $1 / 3$ średniej wartości punktów $\mathrm{z}$ matur (w naszym badaniu $75 \mathrm{pkt}$ ).

Konstruując wzór do obliczania wartości wybieranych na maturze przedmiotów - swoistego stopnia trudności - posłużyliśmy się formułą znaną z IRK. Każdy wydział ma prawo przedstawić własne kryteria przyjmowania kandydatów, obliczania ich punktów rekrutacyjnych. Co naturalne, zasady te mocno się różnią w spektrum oferty UMK. Wzór, którym my się posłużyliśmy, jest wariacją formuły obliczania punktów na jeden z kierunków naszego uniwersytetu. Zmiana polegała na rozszerzeniu stosowania wzoru na wszystkie opcje przedmiotów na maturze, a nie wybrane, jak było pierwotnie.

Przy określaniu kluczowych dla opisu kandydata wartości, odległości od UMK, ustaliliśmy progi do $20 \mathrm{~km}, 20-100 \mathrm{~km}$, powyżej $100 \mathrm{~km}$. Pierwsza wartość to osoby miejscowe - odległość $20 \mathrm{~km}$ została przyjęta jako maksymalny zasięg funkcjonowania komunikacji miejskiej w Toruniu, czyli podstawowy warunek kontaktu młodego człowieka z miastem. Druga wartość analogicznie pokazywała zasięg ruchu lokalnego (szynobusy, autobusy PKS, linie podmiejskie), a także oznaczała umowny zasięg wpływów UMK. W tym promieniu UMK jest ciągle najczęściej wybieraną uczelnią, ale konieczność dalekich dojazdów lub przeprowadzki sprawia, że nie jest tak oczywistym wyborem jak dla „miejscowych” kandydatów. Ostatnia wartość - powyżej $100 \mathrm{~km}$ - oznacza najczęściej osoby, dla których Toruń nie jest najbliższym ośrodkiem akademickim. To osoby, które po drodze na UMK „mijają” inne uczelnie, do których również mają naturalnie dostęp. 


\section{Podsumowanie}

Zaprezentowana baza danych stwarza duże możliwości badawcze, analityczne i interpretacyjne. Stanowi unikalny zbiór danych edukacyjnych i - szerzej - społecznych dotyczących młodych ludzi. Ponad wszelką wątpliwość jej wykorzystanie ma szanse wzbogacić wiele badań socjologicznych, pedagogicznych, dla części może być podstawowym zbiorem danych.

Opisywana baza danych ma daleko większy potencjał do wnioskowania o kondycji poszczególnych kierunków i uczelni, zresztą nie tylko ona. Wszystkie inne bazy wspomniane przez nas wcześniej stanowią gigantyczny zbiór danych domagających się opracowania i interpretacji.

W obliczu coraz powszechniejszych niepokojów społecznych, pogłębiających się nierówności, dziejącego się na naszych oczach głębokiego kryzysu ekologicznego oraz groźnego i całkowicie nieprzewidywalnego zagrożenia epidemiologicznego umiejętność stosowania metody desk research i wykorzystania do własnych badań zastanych baz danych wydaje się rozsądna i bezpieczna.

Jako autorzy pragniemy, aby ten tekst i fragmentarycznie zaprezentowane badania stały się inspiracją do wykorzystywania w podobnym celu IRK jako terra incognita w rozważaniach metodologicznych w Polsce.

\section{Bibliografia}

Bednarowska Z. (2015), Desk research - wykorzystanie potencjału danych zastanych $w$ prowadzeniu badań marketingowych i badań społecznych, „Marketing i Rynek”, 7, s. 23-24. 
